\title{
時間帯別交通量配分モデルの開発と実用化に関する研究
}

\section{MODELLING OF THE TIME-OF-DAY TRAFFIC ASSIGNMENT OVER A TRAFFIC NETWORK}

\author{
藤田素弘*・松井 寛 ${ }^{* *}$. 溝上章志*** \\ By Motohiro FUJITA, Hiroshi MATSUI and Shoshi MIZOKAMI
}

\begin{abstract}
The conventional traffic assignment models presented up to now aim at allocating a set of OD flows of an entire day to a traffic network. In this paper we propose two type of time-of-day traffic assignment models which can describe real traffic flows by hour of the day over a network. Both of the models require some modification of demand flows among the adjacent hours for the conservation law of flows. In the first model, which we call link-flow modification method, the modification is done based on link flows, and in the second model, which we call OD-flow modification method, the modification is done based on OD flows. It is shown that the latter method can be formulated as the Beckmann-type user equilibrium assignment problem. Two models presented here are also compared through the application to the real traffic network.
\end{abstract}

Keywords : traffic assignment, temporal variations in traffic demand

\section{1.はじめに}

今日広く用いられている交通量配分モデルは，そのモ デルの利用目的が主として道路網計画の策定のための需 要予測にあることから, 通常 1 日交通量を対象としてお り，またその配分手法も容量制約の下に需要交通量を与 えられた道路網に合理的に割り付けるといった計画指向 的色彩が強く，道路網上の実際の交通流をできるだけ忠 実に再現するという観点からいえば，今なお多くの問題 点を抱えているといえる。一方，最近では交通量配分を 特定時間帯 (たとえばピーク時間帯) を対象とした交通 運用計画や沿道環境影響の事前評価に使用したいという 社会的要請も強く, 道路網上の交通流を時間を追ってで きるだけ忠実に再現できるような交通量配分モデルの開 発が期待されている.

そこで本論文では 1 日の道路網交通流の時間変動を再 現できる時間帯別交通量配分モデルを開発し，その実用 性について検討を加えたものである．本論文で提案する

* 学生会員 工修 名古屋工業大学院生 社会開発工学科 （ 4 466 名古屋市昭和区御器所町）

** 正会員 工博 名古屋工業大学教授 社会開発工学科 (同上)

*** 正会員 工博 九州東海大学講師 工学部土木工学科 ( ₹862 熊本市大江町渡鹿 223)
時間帯別配分モデルは，単に時間帯別の交通情報を与え るだけにとどまらず，同時に日交通量配分の予測精度向 上にも役立つものと考えられる，それは従来の日単位の 交通量配分が次に挙げる問題点を抱えているためであ る.

（1）最も説得力のある経路選択規範として一般に用 いられている等時間原則 (今日広く用いられている分割 配分法もその近似解を求好方法といえる) は, ほぼ同 時間中に道路上に存在する短時間中の交通流に対して成 立すると考えられ，交通流の定常性が仮定できない 1 日 という時間単位では成立するとはいいがたい。

（2）容量制約を考慮するために導入される交通量一 速度関数または交通量-旅行時間関数（以下これをリン クパフォーマンス関数とよぶ）は，1 時間程度の短時間 であれば実測データからの回帰による合理的な設定方法 が可能であるが，日単位の交通量に対しては実測デー夕 に基づいて決めることができず, いきおい経験的, 観念 的に与えざるを得な( ${ }^{1), 2)}$.

時間帯別交通量配分においては上記の問題点を生じる ことなく, 時間帯別交通量の和として日交通量が比較的 精度よく推定されることが期待できる.

いうまでもなく交通量配分の予測精度向上という観点 からいえば, ネットワークの表現方法, セントロイドの 
扱い方も重要な要因であるが，本研究ではこれらの問題 については特に触れない，また，経路選択規範としては 本論文では等時間原則を用いることにする.

\section{2. 従来の研究と本研究の概要}

1 日を単位として終日の定常的なフローパターンを求 める静的交通量配分手法に対して, 単位時間をきわめて 短く設定し, 状態方程式によって交通流の保存条件を満 足させながら等時間原則に従う時々刻々の交通量を求め る動的交通量配分手法が開発されている ${ }^{3)-5)}$. しかし, この動的手法では状態方程式をネットワーク上の各道路 区間（リンク）ごとに与える必要があるうえ，設定した 道路区間の平均通過時間以下に単位時間を設定する必要 があるため, 静的手法に比べて計算容量および計算時間 は膨大となり，大規模な道路網では実用的な配分手法と はいえない。一方河上・溝上 ${ }^{6}$ は静的配分を基本にして 15 分から 60 分程度の時間帯幅で，一般の道路網上で交 通量配分を行う手法を開発している。ここでは 2 つのモ デルが提案されているが, 両モデルとも静的配分によっ て各経路交通量を求めた後に，互いに隣り合う時間帯で の交通流の保存条件を満足させるために，その経路交通 量をリンク交通量レベルで修正するという手順をとって いる. しかし，この方法では修正計算を行った後に得ら れる解はもはや等時間原則が成立しているかどうか定か ではなく, 解も一意に決まる保障がない，また，このよ うな静的配分を用いて経路交通量を求める場合には，分 割時間帯幅を交通流の定常性が保障できると考えられる 最長トリップ長程度に設定する方が有効であると考えら れるが，この論文では入力デー夕（時間帯別の OD 交 通量なぼ）が信頼できる範囲内でできるかぎり時間帯幅 を短くすることが適切であるとしている.

本研究においても 2 つのモデルを提案するが，1つは 交通流の保存条件のための修正をリンク交通量レベルで 行うモデル（以下では，リンク修正法とよぶ）であり， 上記の河上らのモデルをさらに改良したものとなってい る.このリンク修正法は交通流の定常性を保障すると考 えられる時間帯幅を明示することによって (3. (1) の 仮定 1), 静的配分を基本にした本モデルの意味を明確 なものとし，またその仮定によって河上らのモデルより も簡略化できることを示す.

他の 1 つは，交通流の保存条件のための修正を OD 交通量レベルで行うモデル（以下では，OD 修正法とよ ぶ）である．前者のリンク修正法においては河上らのモ デルと同椂に，保存条件のための修正後の等時間原則お よび解の一意性の保障などの問題が解決されていない が，一方後者の OD 修正法は Beckmann 型最適化問題 として定式化することができ, 修正後の等時間原則およ

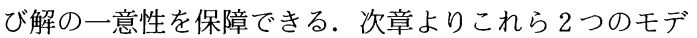
ルについて説明する.

\section{3. リンク修正法}

\section{（1） モデルの定式化}

このモデルは以下の仮定を前提としている.

仮定 1 : 時間帯の幅 $(T)>$ 最長トリップ時間を満足す る.

仮定 2: 各 OD 交通量はセントロイドから同一時間帯 中に一様に発生し, また経路上に一様に分布 する.

仮定 3：内々交通量はゾーン内道路網に一様に分布す る.

さて，まず内々交通量を先に道路網に配分しておく. 最終的に得られる配分交通量は各リンクの断面交通量で あるので, 内々交通量もまた断面交通量で与えなければ ならない. よって, $n$ 時間帯における $s$ ゾーンの内々 交通量を $Q N_{s}^{n}$, 平均トリップ距離を $A L_{s}^{n}, 1$ 車線当た りに換算した道路総延長を $L_{s}$ とおくと, $n$ 時間帯にお ける $s$ ゾーンの 1 リンク 1 車線当たりの内々交通量 $X N_{s}^{n}$ は,

$X N_{s}^{n}=Q N_{s}^{n} \times A L_{s}^{n} / L_{s}$

で表わされる.

次に，互いに隣り合う時間帯での交通流の保存条件を 満足するための修正方法について説明する．いま，通常 の静的配分によって $n$ 時間帯の $i \mathrm{OD}$ ペア間経路 $k$ の 経路交通量 $u_{i k}^{n}$ が与えられているものとする. しかし, その時間帯 $n$ の終端時刻においては, 仮定 2 よりその 時間帯中に出発ノ一ドから出発した車の一部はまだ経路 上に存在しており， $u_{i k}^{n}$ の一部はまだ経路上のすべての リンクを通過しているわけではない。時間帯の幅を $T$, $n$ 時間帯における $i \mathrm{OD}$ ペア間経路 $k$ の出発ノードから $j$ 番目のリンクの終端までの所要時間を $t_{i k}^{n}(j)$ とする と, 経路交通量 $u_{i k}^{n}$ のうち $j$ 番目のリンクの起点をまた 通過していない交通量 $Y 1_{i k}^{n}(j)$ は,

$$
Y 1_{i k}^{n}(j)=u_{i k}^{n} t_{i k}^{n}(j-1) / T
$$

となる.この $Y 1_{i k}^{n}$ の経路上での分布は, 経路の最後の

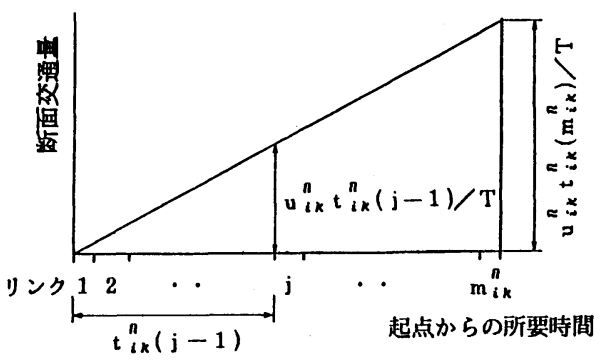

図一1ｎ時間帯において各リンクを通過していない交通量 
リンク順位を $m_{i k}^{n}$ とすると, 経路の全所要時間は $t_{i k}^{n}\left(m_{i k}^{n}\right)$ となるから, 図一1で示すように経路の終端に おいて $u_{i k}^{n} t_{i k}^{n}\left(m_{i k}^{n}\right) / T$ の大きさをもつ三角形分布とな る. よって, $i \mathrm{OD}$ ペア間経路 $k$ の $j$ 番目のリンクを $n$ 時間帯中に通過する断面交通量 $Y_{i k}^{n}(j)$ は,

$Y_{i k}^{n}(j)=Y 1_{i k}^{n-1}(j)+u_{i k}^{n}-Y 1_{i k}^{n}(j)$

となる.上式の右辺第 1 項は 1 つ前の $n-1$ 時間帯で $j$ 番目のリンクを通過できなかった交通量を示し，右辺第 2 項亡第 3 項の差は $n$ 時間帯で通過できる交通量を示 している. また, 上式で $n-1$ 時間帯と $n$ 時間帯で経路 が異なる場合は $Y 1_{i k}^{n-1}(j)=0$ とおけばよい.

実際の配分ではネットワーク上の個々のリンク a につ いて, $Y 1_{i k}^{n}(j)$ を OD ペア $i$, 経路 $k$, およびその経路 での各リンクの順位 $j$ で総和してリンク a の総断面交 通量を求める. リンク a において $n$ 時間帯に通過でき ない交通量の総和 $X 1_{a}^{n}$ は,

$$
X 1_{a}^{n}=\sum_{i} \sum_{k} \sum_{j} \theta_{i k j a}^{n} Y 1_{i k}^{n}(j)
$$

ここで,

$$
\theta_{i k j a}^{n}=\left\{\begin{array}{c}
1: i \mathrm{OD} \text { ペア間経路 } k \text { の } j \text { 番目のリンクが } \\
\text { リンク } \mathrm{a} \text { であるとき } \\
0: \text { そうでないとき }
\end{array}\right.
$$

となる.ここで初めに行う静的配分でリンク a に配分さ れた交通量を $U_{a}^{n}$ とすると, 交通流の保存条件のための 修正後のリンク a の断面交通量 $X_{a}^{n}$ は式 ( 3 ) と同様に,

$$
X_{a}^{n}=X 1_{a}^{n-1}+U_{a}^{n}-X 1_{a}^{n}
$$

となる.この $X_{a}^{n}$ をあらかじめ配分されている内々交通 量に加えたものが， $n$ 時間帯におけるリンク a 総断面 交通量となる。

\section{（2）計算手順}

Step 1 ネットワーク上の交通量の最も少ない時間帯 を時刻の原点に選び $n=1$ とし, $X 1_{a}^{n-1}=0$ と おく.

Step $2 n$ 時間帯の内々交通量を式 (1) より計算し, その内々交通量と $X 1_{a}^{n-1}$ をあらかじめ各リン クのリンクパフォーマンス関数に負荷してお $<$.

Step 3 通常の静的配分を行い, $n$ 時間帯のすべての OD 交通量を配分する.この際すべての経路 とその経路交通量，およびその経路上の各リ ンクまでの所要時間を記憶する.

Step 4 式 (2) より, 各 $i \mathrm{OD}$ ペア間経路 $k$ の $Y 1_{i k}^{n}$ を計算しながら，それを式 $(4)$ より 各リンク aについて累加することによって $X 1_{a}^{n}$ を求める. そして式 $(5)$ より $X_{a}^{n}$ を求 め, 内々交通量を加えて各リンク交通量を求 める.
Step 5 対象とするすべての時間帯で各リンク交通量 を計算できたら終了し，そうでなければ $n=$ $n+1$ として Step 2 へ戻る.

このモデルは動的配分において状態方程式が行ってい る交通流の保存条件のための役割を近似的に取り入れた ものといえるが，動的配分のように状態方程式を明示的 に組み込んで最適化問題を解くモデルとは異なり，修正 を行った後に得られる解が等時間原則を満足している か, また，解が一意に定まるのかという問題点を残して いる.しかしながらこの点を除いて，このモデルの修正 方法は現実に最も即しているといえる.

\section{OD 修正法}

\section{（1）Beckmann 型最適化問題としての定式化}

この配分モデルの前提となる仮定および内々交通量の 扱い方はリンク修正法と同一である. 3. (1) で定式化 したように $n$ 時間帯の $i \mathrm{OD} ヘ ゚ ア$ 間経路 $k$ の経路交通 量 $u_{i k}^{n}$ のうち $n$ 時間帯の終端時刻に経路上の各リンク を通過していない交通量の分布は, 図一2 の実線で示す ような三角形分布となる。しかし，ここで提案する OD 修正法ではその分布を図一2の破線で示すように経路上 の各リンクで一定とし, その值を $u_{i k}^{n} t_{i k}^{n}\left(m_{i k}^{n}\right) / T$ の $1 / 2$ とする.つまり OD 修正法では経路上の各リンクを通 過していない交通量を経路上で平均化する。この平均化 による三角形分布との誤差は, 図一2 からもわかるよう に, 経路中央部ではほとんよ゙なく, その前部で正, 後部 で負となる。しかもこの傾向はどの時間帯でも成り立つ ため，リンク修正法の式（3）からも明らかなように, $n-1$ 時間帯の修正交通量 $\left(Y 1_{i k}^{n-1}\right)$ を加え, $n$ 時間帯の 修正交通量 $\left(Y 1_{i k}^{n}\right)$ を減ずるという関係はこの誤差を常 に小さくする方向に働くから, 各時間帯の平均的なリン ク交通量を得るという目的においては,この平均化の仮 定は許容できるものと考えた。 ただし，この仮定の妥当 性については最終的には配分結果の精度検証によって判 断しなければならない。

さて, リンク修正法の $Y 1_{i k}^{n}(j)$ に相当する修正交通量

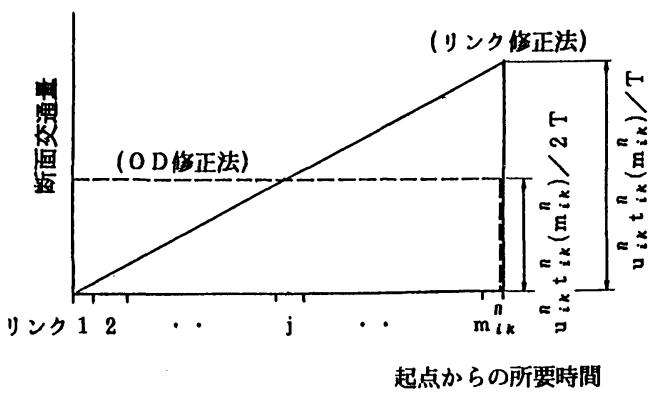

図一2 OD 修正法における交通流の保存条件のための修正方法 
を $v_{i k}^{n}$ とおくと, OD 修正法ではその経路上でのリンク 順位 $j$ に無関係に,

$v_{i k}^{n}=u_{i k}^{n} t_{i k}^{n}\left(m_{i k}^{n}\right) / 2 T$

となる.よって OD 修正法は修正交通量が経路上の各 リンクで一定であるため, 交通流の保存条件を満足する ためにリンク修正法のように個々のリンク交通量を修正 する必要はなく, 経路交通量を修正して配分すればよい. さらに，等時間原則を配分原則としているため各経路の 所要時間 $t_{i k}^{n}\left(m_{i k}^{n}\right)$ はOD 間の最短経路所要時間に等しく なる.この最短経路所要時間を $C_{i}^{n}, n$ 時間帯の $i \mathrm{OD}$ ペア間の $\mathrm{OD}$ 交通量を $\boldsymbol{Q}_{i}^{n}$ とし, $i \mathrm{OD}$ ペア間の各経路 の修正交通量 $v_{i k}^{n}$ の総和を $q_{i}^{n}$ とすると次式が成立する.

$$
q_{i}^{n}=\sum_{k} v_{i k}^{n}=\sum_{k} u_{i k}^{n} C_{i}^{n} / 2 T=Q_{i}^{n} C_{i}^{n} / 2 T
$$

上式より結局，OD 修正法における交通流の保存条件を 満足するためには OD 交通量を修正すればよいことが わかり，たとえば $n$ 時間帯についていえば OD 交通量 $Q_{i}^{n}$ に前時間帯の修正交通量 $q^{n-1}$ を加え, 現時間帯の修 正交通量 $q^{n}$ を除いて配分すればよいことになる.

ところで，以上のように等時間原則を配分規範とする OD 修正法は以下に示す Beckmann 型最適化問題の解亡 して定式化できる7).

$\operatorname{Min}: F_{1}=\sum_{a} \int_{0}^{x_{a}^{n}} C_{a}(y) d y$

$$
-\sum_{i} \int_{0}^{g_{i}^{n}} \frac{2 T}{Q_{i}^{n}}\left(q_{i}^{n-1}+Q_{i}^{n}-z\right) d z
$$

s.t. $\left\{\begin{array}{l}\sum_{k} f_{i k}^{n}-g_{i}^{n}=0 \\ x_{a}^{n}=\sum_{i} \sum_{k} \delta_{i k a}^{n} f_{i k}^{n} \\ f_{i k}^{n} \geqq 0, \quad g_{i}^{n} \geqq 0\end{array}\right.$

ここで,

$x_{a}^{n}: n$ 時間帯におけるリンク a のリンク交通量 $C_{a}(\cdot)$ : リンク a リンクパフォーマンス関数

$Q_{i}^{n}: n$ 時間帯における $i \mathrm{OD}$ ペア間の $\mathrm{OD}$ 交通量

$g_{i}^{n}: n$ 時間帯における $i \mathrm{OD}$ ペア間の交通流の保存 条件のための修正後の OD 交通量

$f_{i k}^{n}: n$ 時間帯における $i \mathrm{OD} ヘ ゚ ア$ 間経路 $k$ の経路交 通量

$q_{i}^{n-1}: n-1$ 時間帯における $i \mathrm{OD} ヘ ゚ ア$ 間の修正交通 量（式（7）による）で, $n$ 時間帯では定数

$$
\delta_{i k a}^{n}:\left\{\begin{array}{l}
1: \text { リンク a が } i \mathrm{OD} \text { ペア間経路 } k \text { に含まれ } \\
\quad \text { るとき } \\
0: \text { そうでないとき }
\end{array}\right.
$$

本問題を解くことによって, リンク修正法で問題となっ た修正後の等時間原則, および解の一意性が証明できる ことを以下に示す.

式 $(8),(9)$ についてラグランジュ関数 $F_{2}^{n}$ を導入 する.

$$
F_{2}^{n}(f, g, \lambda)=F_{1}^{n}(f, g)-\sum_{i} \lambda_{i}^{n}\left\{\sum_{k} f_{i k}^{n}-g_{i}^{n}\right\}
$$

ここに $\lambda_{i}^{n}$ は $n$ 時間帯の $i \mathrm{OD} ヘ ゚ ア に$ 特有のラグラン ジュ乗数である. 式 (10) の最小化問題において $f_{i k}^{n}$ と $g_{i}^{n}$ を独立変数とすると, この問題の最適性の条件は次 のようになる ${ }^{8)}$.

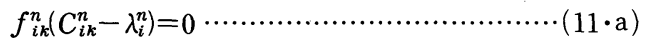

$$
\begin{aligned}
& C_{i k}^{n}-\lambda_{i}^{n} \geqq 0 \\
& g_{i}^{n}\left\{-\frac{2 T}{Q_{i}^{n}}\left(q_{i}^{n-1}+Q_{i}^{n}-g_{i}^{n}\right)+\lambda_{i}^{n}\right\}=0 . \\
& -\frac{2 T}{Q_{i}^{n}}\left(q_{i}^{n-1}+Q_{i}^{n}-g_{i}^{n}\right)+\lambda_{i}^{n} \geqq 0 \cdots \\
& \sum_{k} f_{i k}^{n}-g_{i}^{n}=0
\end{aligned}
$$

ここで $C_{i k}^{n}$ は $n$ 時間帯の $i \mathrm{OD} ヘ ゚ ア$ 間経路 $k$ の経路所 要時間 $\sum_{a} \delta_{i k a}^{n} C_{a}\left(x_{a}^{n}\right)$ である. $\lambda_{i}^{n}$ は $i \mathrm{OD}$ ペア間の最短 経路所要時間と考えてよいから, 式 $(11 \cdot a),(11 \cdot b)$ は等時間原則の定義そのものとなる.

また,

$$
\frac{2 T}{Q_{i}^{n}}\left(q_{i}^{n-1}+Q_{i}^{n}-g_{i}^{n}\right)=D_{i}^{-1}\left(g_{i}^{n}\right)
$$

とすると, 式 $(12 \cdot \mathrm{a}),(12 \cdot \mathrm{b})$ より, $g_{i}^{n}>0$ のとき $\lambda_{i}^{n}=$ $D_{i}^{-1}\left(g_{i}^{n}\right), g_{i}^{n}=0$ のとき $\lambda_{i}^{n} \geqq D_{i}^{-1}\left(g_{i}^{n}\right)$ であり, $\lambda_{i}^{n}$ は OD ペ ア間最短経路所要時間であるから, 式 (15) は $i \mathrm{OD} ヘ 0$ ア間の逆需要関数と考えてよい. 実際には, 3. (1) の 仮定 1 より対象とする時間帯内に 1 台も到着できない OD ペアはないから $g_{i}^{n}$ は常に正である. よって $g_{i}^{n}$ は,

$$
g_{i}^{n}=q_{i}^{n-1}+Q_{i}^{n}-\frac{\lambda_{i}^{n}}{2 T} Q_{i}^{n}
$$

となる. 上式の右辺第 3 項は式 $(7)$ より $n$ 時間帯の 最短経路所要時間 $\lambda_{i}^{n}$ を用いた場合の交通流の保存条件 のための修正交通量と一致する. 式（16）は式（10）の 最適解として得られる $g_{i}^{n}$ が保存条件のための修正後の OD 交通量となることを示しており，これはリンク修正 法の式（5）に対応するものとなっている.すなわち, 式（8)，（9）を最適化すれば OD 修正法で仮定した 交通流の保存条件を満足する修正後の OD 交通量, お よび等時間原則を満足するリンク交通量の解 $\left(g_{i}^{n}, x_{a}^{n}\right)$ を 得ることができるのである. 解の一意性は, 式 (8) の 右辺第 1 項のリンクパフォーマンス関数と, 第 2 項の逆 需要関数がそれぞれ凸関数であれば保証される ${ }^{9)}$. リン クパフォーマンス関数は一般に凸関数であり，また逆需 要関数は図一3のような疑似凸関数である線形関数とな るため, 式 (8)，（9）の解は一意に決まる.

\section{(2) 計算手順}

問題 $F_{1}$ は一般的によく知られている発生集中量制約 のない需要変動型交通均衡問題と全く同形の最適化問題 であるが，このような問題は $F-W$ 法によって最適解 


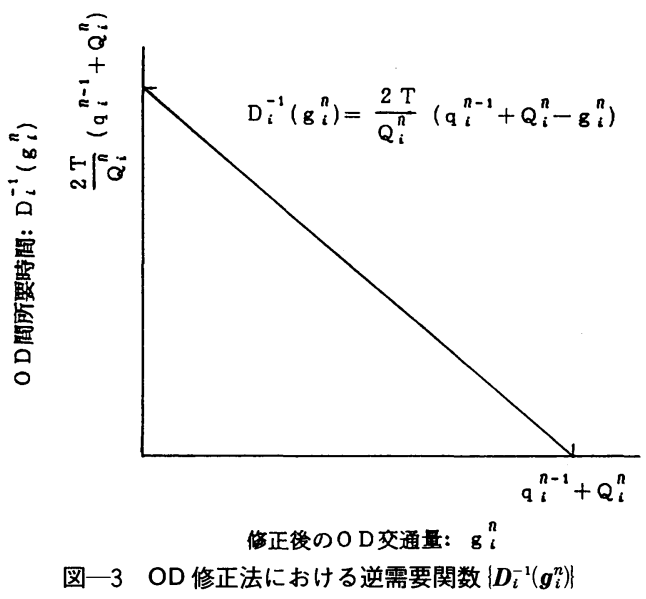

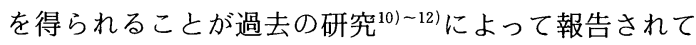
いる．本研究でもそれにならい $F-W$ 法によって解く ことにすると, 対象とするすべての時間帯 $n$ で最適解 を得るための計算手順は次のようになる.

Step 1 ネットワーク上の交通量の最も少ない時間帯 を時刻の原点に選び $n=1$ とし,$q_{i}^{n-1}=0$ と おく.

Step $2 n$ 時間帯の内々交通量を式 ( 1 ) より計算し, あらかじめ各りンクのパフォーマンス関数に 負荷しておく

Step $3 k=1$ として初期実行可能解 $g_{i}^{n(k)}, x_{a}^{n(k)}$ を与え る.

Step $4 x_{a}^{n(k)}$ に応じた所要時間を計算し, 最短経路探 索によって各 OD 間の所要時間 $C_{i}^{n(k)}$ を求め る.

Step 5 Step 4 で求められた $C_{i}^{n(k)}$ を式 (16) の $\lambda_{i}^{n} に$ 代入することによって OD 交通量 $\bar{g}_{i}$ を求め る.

Step 6 最短経路に $\bar{g}_{i}$ をすべて負荷する All-ornothing 法により $\bar{x}_{a}$ を求める.

Step 7 あらかじめ設定した $\varepsilon_{1}, \varepsilon_{2}$ に対して,

( a ) $\quad \sum_{a}\left(\bar{x}_{a}-x_{a}^{n(k)}\right) C_{a}\left(x_{a}^{n(k)}\right) \leqq \varepsilon_{1}$

( b ) $\quad \operatorname{Max}_{a}\left|\left(\bar{x}_{a}-x_{a}^{n(k)}\right) / x_{a}^{n(k)}\right| \leqq \varepsilon_{2}$

(c ) $k>K(K$ は任意に与える $)$

のいずれかを満足するならば， $x_{a}^{n(k)}$ に内々交 通量を加えてリンク交通量を求めStep 11 人 行 $<$.

Step $8 \quad g_{i}^{n}=\alpha g_{i}^{n(k)}+(1-\alpha) \bar{g}_{i}$

$x_{a}^{n}=\alpha x_{a}^{n(k)}+(1-\alpha) \bar{x}_{a}$

とおき,一次元探索によって目的関数式 (8)

を最小にする結合パラメーター $\alpha^{(k)}$ を求め る.
Step 9

$$
g_{i}^{n(k+1)}=\alpha^{(k)} g_{i}^{n(k)}+\left(1-\alpha^{(k)}\right) \bar{g}_{i}
$$$$
x_{a}^{n(k+1)}=\alpha^{(k)} x_{a}^{n(k)}+\left(1-\alpha^{(k)}\right) \bar{x}_{a}
$$

により, OD 交通量, リンク交通量の修正を 行う.

Step $10 k=k+1$ とおいて Step 4 へ戻る.

Step 11 対象とするすべての時間帯でリンク交通量 を計算できたら終了する.そうでなければ 式 $(7)$ より $q_{i}^{n}$ を計算し,$n=n+1$ とし て Step 2 へ戻る.

時間帯の幅 $T$ は交通流の定常性を保証するため仮定 1 を満足するように設定する必要があるが, 実際には計 算の途中で $T$ を越えるトリップ長が出現し仮定 1 が満 たされなくなる可能性がある. しかし, 図一3の逆需要 関数の縦軸の切片から, 最短経路所要時間が $T$ の 2 倍 以上の $2 T\left(Q_{i}^{n}+q_{i}^{n}\right) / Q_{i}^{n}$ 以下であれば $g_{i}^{n}$ は必ず正であ り，また 4. (1) の定式化からそれ以上の最短経路所要 時間になったとしても最適解が得られないわけではな い. $T$ を越えるトリップが少なければ, 再度 $T$ を変え て計算しなおす手間を省き，その計算結果をそのまま用 いてもさしつかえないと考えられる.

\section{5. 配分結果と考察}

本研究で提案したリンク修正法，および OD 修正法 を実際の道路網に適用し，それぞれの実績再現性を検証 する. 比較のため, 交通流の保存条件のための修正を施 さない通常の静的配分を各時間帯別に独立に行った場合 も同様に検証する．配分は豊田市の道路網で行い, 28 セントロイド, 88 ノード, 278 リンクの中規模のネット ワークを用いるが，このネットワークはほぼ豊田市の補 助幹線道路以上の道路網に対応している (図一4). 配分 に用いる時間帯別の OD 交通量は昭和 56 年度パーソン トリップ調査のマスターテープから出発時間をベースと して集計する．豊田市の最長トリップ長が 52 分である ので, 3. (1) の仮定 1 を満たす時間帯の幅 $T$ を 60 分 とする. 以下の分析では道路網上の交通量が最小となる 午前 3 時から配分を始め 24 回の繰返しによって 1 日の 時間帯別配分交通量を求めるが，たとえば特定時間帯 (ピーク時間帯など) の交通状況のみを知りたい場合の 実用性を考えて, 対象亡する時間帯の 1 つ前の時間帯か ら配分を始める場合についても後に触れる. リンク修正 法で初めに行う静的配分, 交通流の保存条件のための修 正を施さない時間帯別配分，および日単位の配分には $F-W$ 法による等時間原則配分を適用し, リンクパ フォーマンス関数には以下に示す修正 BPR 関数を用い $た^{13)}$.

$C_{a}\left(x_{a}\right)=C_{a}(0)\left\{1+2.62\left(x_{a} / D_{a}\right)^{5}\right\}$

ここに, $C_{a}(0): x_{a}=0$ におけるリンク走行時間 


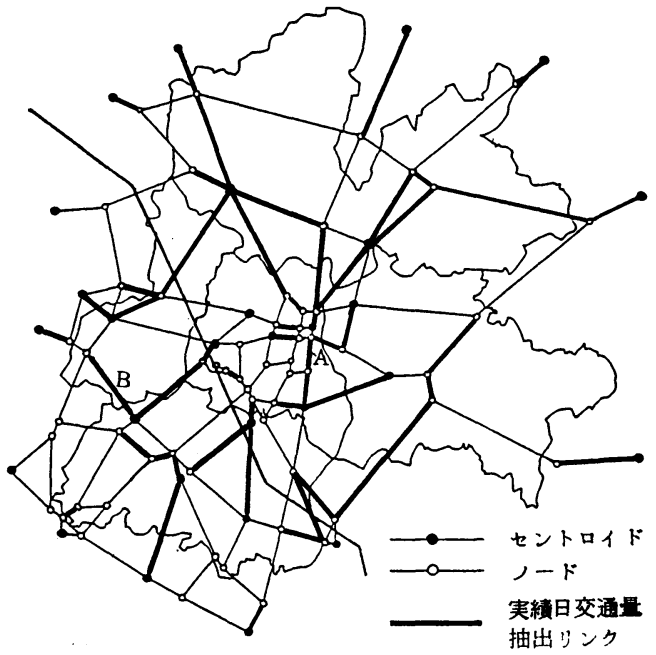

図一4 分析に用いたネットワーク図

\section{$D_{a}$ :リンク a の可能交通容量}

ここで, 時間可能交通容量は「道路の交通容量 $1^{14)}$ で定 義されている算定方法によって求め, 日可能交通容量は 昭和 56 年度パーソントリップ調査に使われたものを用 いるが，これは平均的な $K$ 值と $D$ 值を用いて求められ ている.

なお，適合度分析には推定值と実績值の RMS 誤差お よび相関係数を用いるが，そのうち RMS 誤差は次式よ り求める.

$$
\text { RMS 誤差 }=\sqrt{\sum_{i}^{n}\left(X_{i}-\bar{X}_{i}\right)^{2} / n} \text {. }
$$

\section{$X_{i}$ : リンク $i$ の推定交通量}

$\bar{X}_{i}$ : リンク $i$ の実績交通量

$$
n: \text { デー夕数 }
$$

\section{（1）各時間帯の適合度分析}

上記の 3 つの時間帯別配分モデルについてピーク，才 フピーク時の実績再現性を比較する. 分析に用いる各時 間帯別の実績交通量は, 昭和 55 年度道路交通センサス の原票より抽出したもので（デー夕数 42 個, そのリン クは図一4の実績日交通量抽出リンクに含まれる), 各 時間帯 1 時間の両方向合計の断面交通量である. 得られ た分析結果は次のとおりである.

(1) ピーク時 (午前 7 時台) の適合度比較 (表一1) では，修正後の等時間原則を保証できる OD 修正法は RMS 誤差, 相関係数とも 3 つの配分の中で最も良い結 果を示しているが，リンク修正法は相関係数が 0.462 と 悪く, 修正なしの配分は RMS 誤差が他の配分に比べて かなり悪くなっている.これを図一5の実績値と推定值 の散布図でみると, OD 修正法は実績值に対してほぼ 45 度の直線の周りでばらついており, その大きさも比 較的小さいが，リンク修正法はばらつきが大きく，しか もばらつきにバイアスがみられる.修正なしの配分は交 通流の保存条件を考慮していないため, 全体的に実測值 よりもかなり過大な交通量を推定している.

(2) オフピーク時 $(13,14$ 時台) における適合度比較

表一1 ピーク時（午前 7 時台）のリンク交通量（台/時）の適 合度比較

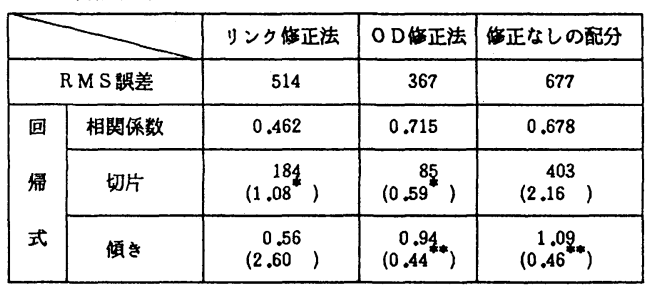

注）（）内は $\mathrm{t}$ 值，*，**は有䓡水筆 $5 \%$ にる検定結果 *回绎直線の切片が0であろ、という仮説が寨却されない。 **回㷌直線の傾きが 1 である、という仮説が裹却されない。

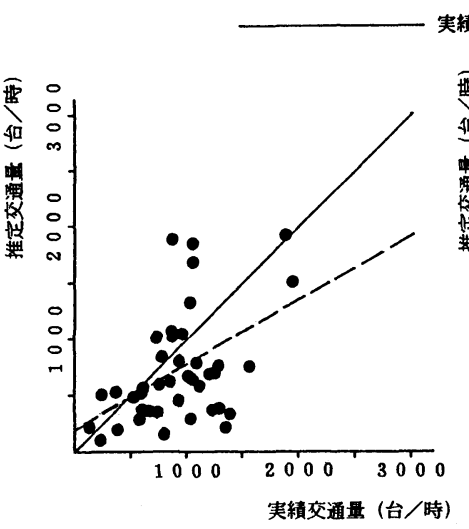

（a）リンク信正法

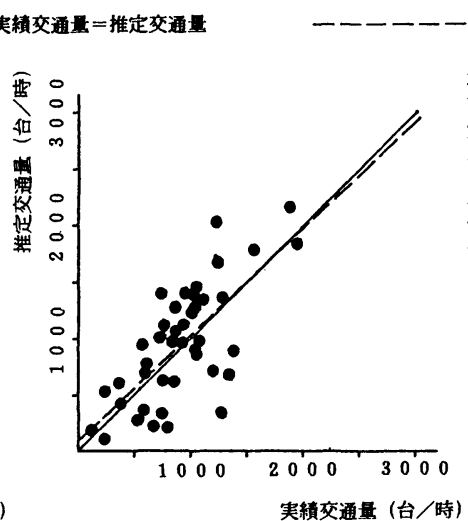

(b) OD华正法
一七回㷌䗷

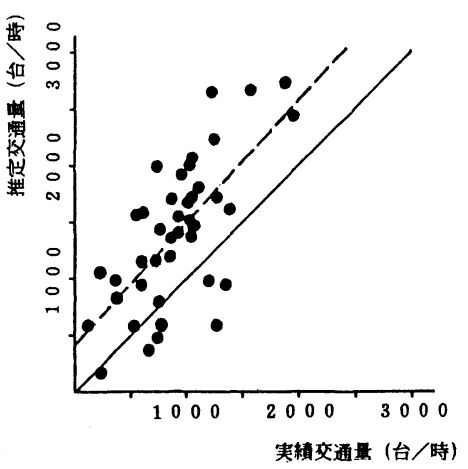

(c) 正なしの配分

図一5 ピーク時（午前 7 時台）のリンク交通量（台/時）の実績值と推定値の散布図 
表一2 オフピーク時（13，14 時台）のリンク交通量（台/時） の適合度比較（RMS 誤差）

\begin{tabular}{|c|c|c|c|}
\hline & リンク修正法 & O D 修正法 & 修正なしの配分 \\
\hline 13 時台 & 260 & 262 & 265 \\
\hline 14 時台 & 267 & 266 & 269 \\
\hline
\end{tabular}

（表一2）では，3つの配分ともほとんど変わらない結 果となっている.これはオフピーク時では前後の時間帯 で交通流がほぼ定常的に流れているために，加えるべき 前時間帯の修正交通量と減ずるべき現時間帯の修正交通 量が均衡し, 交通流の保存条件の影響が見掛け上相殺さ れているためと考えられる.

(3) リンク修正法, OD 修正法によって推定した交通 量の時間変動パターン（図一6(a), (b)) では, 全体的 によ゙ちらの配分も比較的よく推定しているが，部分的に みるとリンク修正法で推定した朝夕のピーク交通量が大 きくずれており，誤差が大きくなっている．このように ピーク時においてリンク修正法の誤差が大きくなるの は, リンク修正法が修正後の最適解として得られる旅行 時間ではなく修正前の実際と異なった旅行時間を用いて 修正を行うためと考えられ, 特にピーク時のように旅行 時間の変動が大きい時間帯では修正前の旅行時間の実際 との差が大きくなるため, 誤差が大きくなると考えられ る.

以上の結果から，オフピーク時では交通流の保存条件 のための修正を行う必要性は高くないが，ピーク時での 必要性はむしろ高く, またその場合には修正後の最適解 が得られる OD 修正法でないと誤差がかなり大きくな ることがわかる. しかし, オフピーク時においても局所 的に混雑するリンクがあり，この場合にはピーク時と同 様の扱いをする必要がある. 結局 3 つの時間帯別配分の 中では全時間帯を通じて解の安定度が高く, 精度良く時 間帯別交通量を推定できるOD 修正法が最も実用的で あると考えられる. また以上の結果より, OD 修正法に おいて 4. (1) で仮定した平均化の仮定はおおむね許容 できるものであることがわかる.

さて，1日 24 時間の時間帯別交通量ではなく, 特定 時間帯のみの配分交通量が必要な場合の簡便法として, 当該時間帯の 1 つ前の時間带から配分を始めた場合（計 算手順は 4. ( 2 ) と同様) の適合度について考える. 表 ー3 は OD 修正法についてピーク時, オフピーク時の各 時間帯で推定した交通量の RMS 誤差で, 配分を午前 3 時から始めた場合と当該時間帯の前時間帯から始めた場 合のそれぞれについて示している. それによると, 前時 間帯から配分を始めた場合の RMS 誤差は午前 3 時から 始めたものとほとんど変わらないことがわかり，実際の 配分では前時間帯から配分を始めても精度面で問題はな

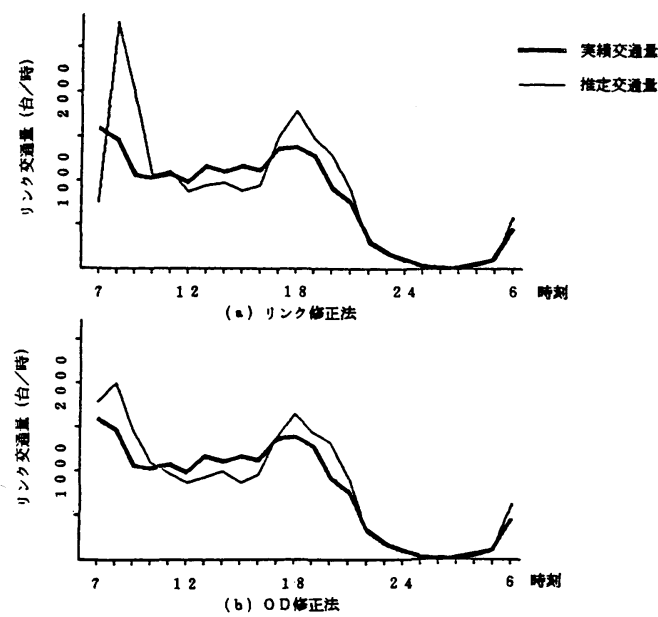

図一6（a ）リンクA（図一4 参照) の時間変動パターンの適合 度比較
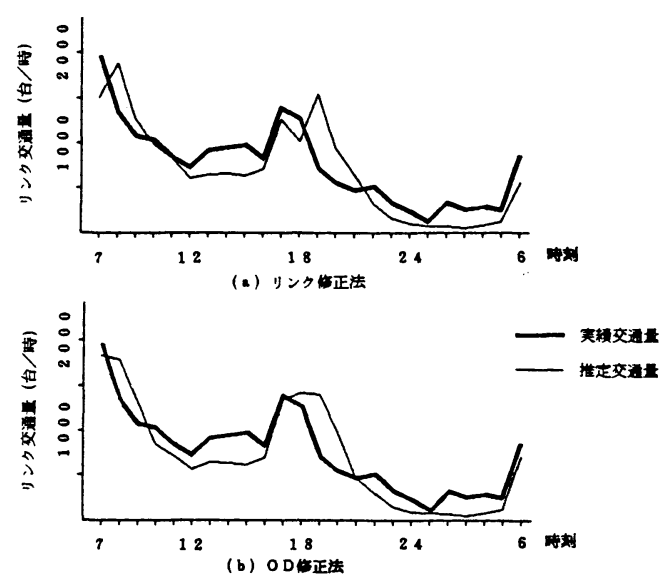

図一6(b) リンクB (図一4 参照) の時間変動パターンの適合 度比較

表一3 OD 修正法の配分開始時間帯の違いによる適合度比較 (RMS 誤差)

\begin{tabular}{|c|c|c|c|c|}
\hline \multirow{2}{*}{} & \multicolumn{2}{|c|}{ ピーク時間帯 } & \multicolumn{2}{|c|}{ オフピーク時間帯 } \\
\cline { 2 - 5 } & 7 時台 & 8 時台 & 13 時台 & 14 時台 \\
\hline $\begin{array}{c}\text { 午前 3 時 } \\
\text { からの配分 }\end{array}$ & 367 & 396 & 262 & 266 \\
\hline $\begin{array}{c}\text { 前時間帯 } \\
\text { からの配分 }\end{array}$ & 369 & 399 & 263 & 266 \\
\hline
\end{tabular}

いと考えられる.

\section{（2）日単位の配分との比較}

ここでは，3つの時間帯別配分モデルのそれぞれにつ いて 1 日 24 時間の配分結果を累加して推定した日交通 量と, 日単位配分によって推定した日交通量を比較検討 する. 分析に用いる実績日交通量は, 昭和 55 年度道路 
交通センサスの報告書 ${ }^{15)}$ から日交通量として直接得られ たもの (6 個), 報告書の昼間 12 時間交通量デー夕に豊 田市の昼夜率の平均值（1.356）を乗じて日交通量の実 績値としたもの（44 個）の計 50 個（図一4参照）で, いずれも両方向合計の交通量である. 表一 4 の日交通量 の適合度比較によれば，相関係数，RMS 誤差ともに時 間帯別配分モデルで推定した方が日単位の配分で推定す るよりも良い結果を示している．これを図一7の実績値 と推定值の相関図で判断すると, 時間帯別配分モデルで 推定した日交通量はどれもほぼ 45 度の直線の周りでば らついているが，日単位の配分で推定した日交通量は実 績值の低い所では過大に, 高い所では過小に推定されて おり，道路網全体にわたって交通量分布が平均化されて

\section{表一4 日単位の配分と各時間帯別配分の適合度比較}

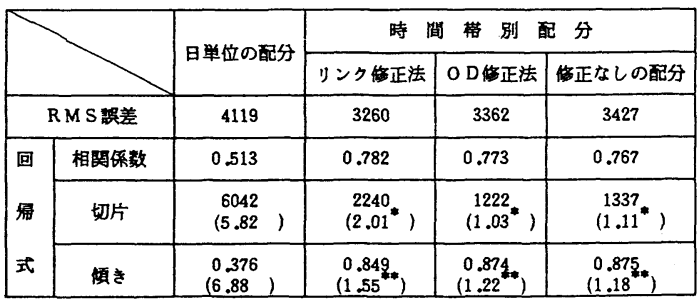

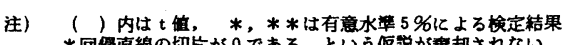

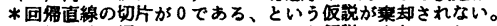

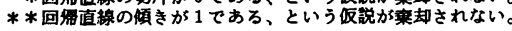

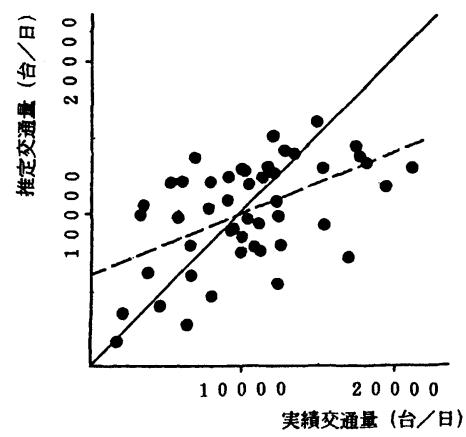

（*） 日単位の配分

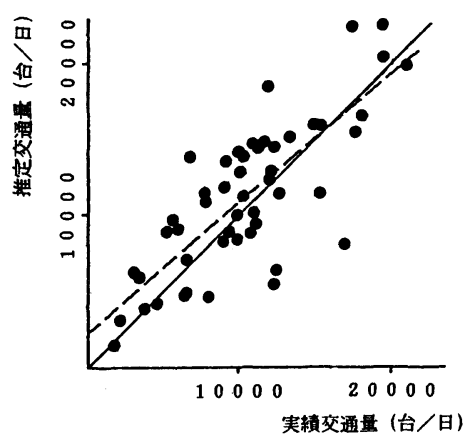

（a）リンク修正法

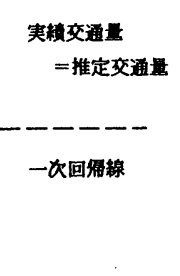

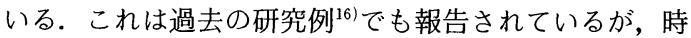
間帯別配分モデルの結果と比較するとこの平均化の傾向 は，1. で述べた日単位の配分の問題点が無視できない ことを示すものと考えられ，本研究で提案した時間帯別 配分手法はこの点を改善しているという意味で有益な方 法といえる.

ところで5.（1）ではピーク時に大きく誤差を生じて いたリンク修正法, 交通流の保存条件のための修正をし ない配分も，日交通量の予測では OD 修正法と同様の 比較的良い結果となっている.これは 1 日の総 $O D$ 交 通量は修正方法の違いによって変化せず保存されるた め, 各時間帯の 1 日の総和をとれば結局どの方法によっ てもほぼ同一の結果となったものと考えられる．これは また保存条件のための修正にかかわる誤差は，1日の総 和をとることによってそのほとんどを消去できるもので あることを示していると考えられ，日交通量の予測のみ を対象とする場合ではリンク修正法, 修正なしの配分も $\mathrm{OD}$ 修正法と同様に実用的と考えられる.

最後に各種配分手法における計算容量および計算時間 を表一5にまとめておく.リンク修正法は配分の際に全 経路を記憶しておく必要があるため他の手法と比べて計 算容量がかなり大きくなっている，また，各時間帯別配 分によって日交通量を求める場合の計算時間は単にピー ク時の 1 時間当たりの計算時間を 24 倍したものになっ ていない。これは夜間のように交通量の少ない時間帯で

表一5 各種配分手法の計算容量（REGION）および計算時間

\begin{tabular}{|c|c|c|c|c|c|}
\hline & \multirow{2}{*}{ 日単位の配分 } & \multicolumn{3}{|c|}{ 時 間 带 別 配 分 } \\
\hline & & & リンク正法 & O D修正法 & 徏正なしの配分 \\
\hline \multicolumn{2}{|c|}{ REGION (KB) } & 102 & 3363 & 182 & 111 \\
\hline \multirow{2}{*}{$\begin{array}{l}\text { 計 } \\
\text { 算 } \\
\text { 時 } \\
\text { 間 } \\
\text { (分) }\end{array}$} & $\begin{array}{c}1 \text { 時间带 } \\
\text { (ピーク時) }\end{array}$ & - & 5.05 & 5.67 & 4.96 \\
\hline & 1 日 & 5.18 & 74.75 & 85.97 & 56.48 \\
\hline
\end{tabular}

注）上記は28セントロイト，88ノード，278リンクのネットワークの埸合で、 計算機には MELCOM-COSMO 700 II/MPを使用した。

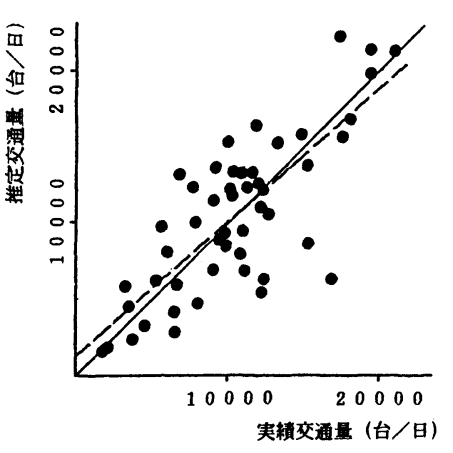

（b）ＯD徏正法

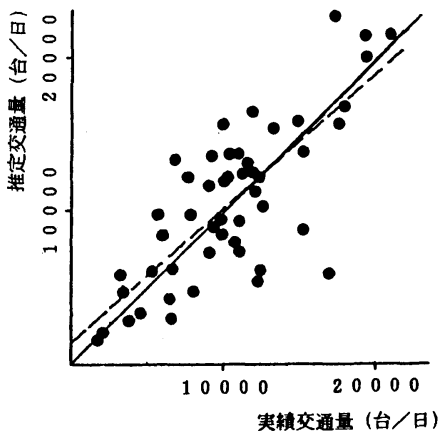

(c) 紫正なしの配分

図一7 日交通量（台/日）の実績值と推定値の散布図 
はOD 交通量のほとんどが最短経路に流れるために, 収束させるための計算回数がピーク時に比べて少なくて すむからである。

なお，本研究では内々交通量を考慮して計算を行った が，それによると各リンクに配分される全交通量のうち 内々交通量が占める割合は $5 \%$ 程度であった。この程 度の内々率の場合では内々交通量を無視しても解にほと んど影響を与えないことも明らかとなった。

\section{6. 結論と今後の検討課題}

本研究においては交通運用計画や沿道環境影響の事前 評価に用いるための時間帯別の交通状況を再現すること と, 日単位の交通量配分の予測精度向上を目的として, 一般の道路網を対象とした 1 時間程度で適用することが できる実用的な時間帯別配分モデルの開発を行った。時 間帯別配分モデルとして $2 つ の$ 方法を提案したが，1つ は通常の静的配分の後，互いに隣り合う時間帯での交通 流の保存条件を満足させるために, リンク交通量レベル で修正を行うリンク修正法であり，他の 1 つは OD 交 通量レベルで修正を行う OD 修正法である. 本研究で 得られた結論は次のとおりである.

（1）交通流の保存条件を満足させるための現実に最 も即した修正方法としてリンク修正法を提案したが，こ の方法は初めに仮定した等時間原則が最終的に満足され る保障がないこと，および解の一意性が保障されないこ とが明らかとなった。

（2）等時間原則を用いたときの OD 修正法が Beckmann 型最適化問題として定式化できることを明らかに し，この方法においては最終的な時間帯別交通量におい て等時間原則と解の一意性が保障されることを示した。

（3）リンク修正法，OD 修正法および修正なしの時 間帯別配分の適合度比較から，オフピーク時では交通流 の保存条件のための修正の必要性は高くないが，ピーク 時ではむしろ高く，またピーク時では OD 修正法のよ うな修正後の最適解が得られる方法でないと誤差が非常 に大きくなることがわかった．結局全時間帯を通じて精 度良く時間帯別交通量を推定できる OD 修正法が最も 実用的であることがわかった。

（4）時間帯別配分モデルと日単位の配分のそれぞれ によって推定した日交通量を比較したところ，日単位の 配分によって推定した推定值は，実績值の低いところで 過大に，高いところで過小に推定されており，道路網全 体にわたって交通量分布が平均化されていることがわ

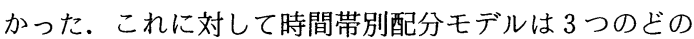
方法によっても比較的良い結果を示しており，日交通量 の予測のみを対象とする場合にはどの時間帯別配分モデ
ルについても実用的であることがわかった。

以上の結論は豊田市の道路網への適用結果から得られ たものであるが，さらに信頼性を高めるには，他のネッ トワークへの適用が必要である. また本時間帯別配分モ デルを長期予測に適用するとき，配分の対象とする時間 帯別 OD 交通量をいかに予測するかの問題が残されて おり，これは今後の課題である. 最後に本研究の適用計 算にあたって，中部都市圈総合都市交通計画協議会より パーソントリップ調査のマスターテープの提供を受け, 建設省中部地方建設局道路計画第二課より実測データの 提供を受けた。ここに感謝を申し上げます。

\section{参 考 文 献}

1）北川 久・太田勝敏：配分手法で用いる $Q-V$ 式に関す る考察, 交通工学, Vol. 19, No. 3, pp.4 13, 1984.

2）松井 寛・藤田素弘：交通量配分における $Q-V$ 式の設 定方法に関する研究, 土木計画学研究・論文集, No. 3, pp. 153〜160, 1986.

3）松井 寛：総走行時間最小化配分亡等時間配分の動的化, 土木学会論文報告集, No. 339, pp. 239～242， 1983.

4）松井 寛・丹羽知紀：道路網上の経路誘導に関する基礎 的研究, 土木計画学研究 - 論文集, No. 4, pp. 85 92, 1986.

5) Chu, K. C. and Gazis, D. C. : Dynamic Allocation of Parallel Congested Traffic Channels, Proc. of 6th Int. Symp. on Transportation and Traffic Theory, pp. 307 326, 1974.

6）河上省吾・溝上章志・鈴木稔幸：交通量の時間的変動を 考慮した道路交通量配分手法に関する研究，交通工学， Vol. 20, No.6, pp. $17 \sim 25,1985$.

7）藤田素弘：時間変動を考虑した交通量配分手法とその評 価に関する研究, 名古屋工業大学修士論文.

8）今野 浩-山下 浩：非線形計画法, 日科技連, 1978.

9) Beckmann, M. J., MeGuire, C.B. and Winston, C. B. : Studies in the Economics of Transportation, Yale University Press, 1956.

10）溝上章志：需要変動を考慮したバス輸送計画策定法に関 する基礎的研究, 名古屋大学学位論文, 1985 .

11）宮城俊彦：交通ネットワークの理論と計算法, 京都大学 学位論文, 1982.

12）加藤 晃・宮城俊彦・吉田俊和：交通分布・配分結合乇 デルとその実用性に関する研究，交通工学, Vol. 7, pp. 287 294, 1985 .

13) Steenbrink, P.A. : Optimization of Transport Networks, John Willey \& Sons, 1974.

14）日本道路協会：道路の交通容量, 1984.

15）建設省中部地方建設局：昭和 55 年度道路交通センサス報 告書 一般交通量調查編（3の 1) 箇所別基本表, 1981.

16）佐佐木綱・朝倉康夫：OD 需要の変動を内生化した最適 道路網計画モデル，土木学会論文集・IV, No. 383, pp. 93 102, 1987 .

(1987.6.8 • 受付) 